\title{
A Review on Himalayan Pine Species: Ethnopharmacological, Phytochemical and Pharmacological Aspects
}

\author{
Aditi Sharma, Lalit Sharma, Rohit Goyal ${ }^{*}$
}

\section{Aditi Sharma, Lalit Sharma, Rohit Goyal*}

School of Pharmaceutical Sciences, Shoolini University, Solan, Himachal Pradesh, INDIA.

Correspondence

\section{Dr. Rohit Goyal}

School of Pharmaceutical Sciences, Shoolini University, Solan, Himachal Pradesh, INDIA

Phone no : +91-98160-62679

E-mail: rohit_pharm@yahoo.co.in

History

- Submission Date: 01-03-2018;

- Review completed: 14-03-2018;

- Accepted Date: 11-05-2018

DOI : 10.5530/pj.2018.4.100

Article Available online http://www.phcogj.com/v10/i4

\section{Copyright}

(c) 2018 Phcog.Net. This is an openaccess article distributed under the terms of the Creative Commons Attribution 4.0 International license.

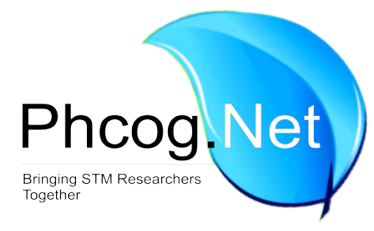

\begin{abstract}
Introduction: Ever since ancient times, medicinal plants recognized as major source of therapeutics, as rescue for human diseases and maintain health. There is an exponential increase in usage of green medicines due to less cost and fewer side effects. The family Pinaceae, is largest conifer in species diversity. Pinus is the largest genus of monoecious, resiniferous, evergreen trees commonly known as Pines. Three species of pines occur wild in Indian Himalayas Pinus roxburghii, Pinus wallichiana, Pinus gerardiana. In addition, the constituents present in these plants are beneficial for the purpose of treatment of various ailments. Methods: Information was collected from scientific journals, books, and reports via electronic search tools( Medline, Pubmed etc.) Results: This review summarizes the existing information on three species of Pinus in relation to their pharmacognostic properties, phytochemistry, ethanopharmacology and pharmacological activities.

Key words: Pinus, Himalayas, Pinus roxburghii, Pinus wallichina, Pinus gerardiana, Phytochemistry, Pharmacology, Ethanopharmacology.
\end{abstract}

\section{INTRODUCTION}

Medicinal plants are recognized as major source of therapeutics, throughout human history to fight illness and maintain health. The usage of natural product in treatment of diseases has been increased because of its natural source and comparatively lesser side effects as compared to the complexity in formulating chemical based drugs, as well as uprising cost has led worldwide researchers to focus on the medicinal plant research. The plant extracts possess medicinal properties and are often used as sweetening agent, colouring agent, preservatives in many medicinal formulations. ${ }^{1}$ India has a rich diversity of medicinal as well as aromatic plants and holds a unique place in the world in the traditional system of medicine thus called medicinal Garden of the world. India is one of the twelve mega biodiversity center having over 45000 plant species. ${ }^{2}$ Pinus is the most common genus of the family Pinaceae, which in turn is the largest family within the coniferous. It is a large genus with over 110 species worldwide. ${ }^{3}$ The genus is divided into two subgenera: Strobus (Haploxylon, soft pines) and Pinus (Diploxylon, hard pines). ${ }^{4}$ Five species of pines are indigenous to India viz.P. roxburghii (Chir pine), P.wallichiana (Blue pine), P. kesiya (Khasi pine), P. gerardiana (Chilgoza pine) and P. merkussi (Teriasserian pine). ${ }^{5}$ Among all $P$. roxburghii, $P$. wallichiana and $P$.gerardiana are found in the Himalayas, whereas P. kesiya and P.merkussi are indigenous to Assam (India) and Burma.

The Indian Himalayan region, a birthplace of Ayurveda and alternative therapies, covers about $18 \%$ of India and extends more than $2,800 \mathrm{~km}$ long and $220-300 \mathrm{~km}$ wide with altitudes of $200-8000 \mathrm{~m}$. India fulfills $80 \%$ demand of Ayurvedic medicine, $46 \%$ of Unani drugs and $33 \%$ of allopathic drugs. ${ }^{6,78}$ The unique climatic conditions enable a rich array of growth of various medicinally useful plants. ${ }^{8}$ Pinus species are important forest primarily for timber interests and source of gum oleoresins. Three species of Pinus plants are abundantly found in Himachal Pradesh i.e. Pinus roxburghii, Pinus wallichiiana and Pinus gerardiana. P. roxburghii Sarg (chir pine) is a tall tree with spreading crown grows at an altitude of 4502400m from Kashmir to Bhutan and Siwalik hills. ${ }^{9}$ P. wallichiana (blue pine) found at an altitude 2000$3500 \mathrm{~m}$ whereas $P$. gerardiana, commonly (Chilgoza pine) found at an altitude of $1600-3000 \mathrm{~m}$ in district Kinnaur of Himachal Pradesh (H.P.). The present review was aimed to aware the researchers about the potential of Pinus species from Himalayas and to fully explore the scientific basis for the medicinal uses of these plant species.

\section{Pinus roxburghii Habitat and morphology}

Pinus roxburghii Sarg. (Pinaceae) is an older terrestrial ornamental plant in the world. It is the most important pine of North Western Himalayas and an important resin and timber yielding species. In India it is found in Himachal Pradesh, Kashmir and Uttaranchal. ${ }^{10}$ It is a large tree with spreading crown 
reaching 30-50 m with a trunk diameter of up to $2 \mathrm{~m}$. It is found at the height of 500 to $2,500 \mathrm{~m}$ above sea level and grows gregariously. ${ }^{11}$ It is a large tree with branches in more or less whorled, bark dark gray, often reddish, deeply fissured, rough, exfoliating in longitudinally elongated plates, leaves in clusters of three, $20-30 \mathrm{~cm}$, long, triquetrous, finely toothed, needle like, light green, persisting on an average for a year and a half; male flowers about $1.5 \mathrm{~cm}$ long, arranged in the form of cones, female cones, solitary or 2-5 together, ovoid, $10-20 \mathrm{~cm} \times 7.5 \times 13 \mathrm{~cm}$ when ripe. ${ }^{9}$ The tapping of the stem produces clear, transparent oleo-resin with the pungent and bitter taste. Taxonomy and common names of Pinus roxburghii Sarg are shown in Table $1 .{ }^{12}$

\section{Phytochemical constituents}

P. roxburghii is known to be a rich source of terpenoids, flavonoids, tannins, xanthones other compounds shown in Table 2. Structure of different bioactive compounds are given in Figure 1a, 1b, 1c.

\section{Ethnopharmacological uses}

Pinus roxburghii has been widely used as a traditional remedy by the local tribes in various parts of Northern India. The wood oil is antiseptic, diaphoretic, rubefacient, aromatic and carminative in nature. It is used as nerve tonic and expectorant and as remedy for diseases of the eye, ear, pharynx, hemorrhages, worm infestations and skin..$^{20}$ The bark paste is applied in burns, scalds and ulcers. The timber is largely used for various purposes e.g., matchbox industry, sports goods, musical instruments, house building, furniture, tea chests etc. The volatile component of resin known as turpentine oil is the most important basic raw material for the synthesis of terpene chemicals widely used as adhesives, lubrication, solvents, plasticizers, paints and varnishes, antiseptic and expectorant. It is included in the Indian Pharmaceutical Codex as Oleum terebintinae for treatment of chronic bronchitis. ${ }^{21}$ Turpentine oil is applied externally as rubefacient in lumbago and arthritis. It is also used as remedy for neuralgia, minor hemorrhages of tooth sockets and also recommended in gangrene of lungs. ${ }^{22}$ It is used to arrest minor haemorrhages in tooth sockets and nose. In the form of enema used in obstinate constipation. Inhaling the vapors of turpentine is useful in bronchitis. Resin (Biroja) is obtained as solid residue in the distillation of turpentine oil from oleoresin. It is used for bangles, varnish, paints, polish industries, ingredient of printing inks, batteries. To heel cracks boiled resin (khaida or leesa) are used. The carbon is collected from the burnt resinous wood (doi) of P. roxburghii mixed with mustard oil and is made into a paste (kajal), which is applied inside the lower eyelids to keep the eyes clean and attractive. ${ }^{23}$ The resin mixed with the ash of Betula utilis is commonly applied over sprains and plastered on fractured bone for quick recovery, soften scar tissue and consumed as remedy in worm infestation and gastric trouble. ${ }^{24}$ The resin is a stimulant and used internally as stomachic

\section{Table 1: Taxonomy of Pinus roxburghii.}

\begin{tabular}{ccc}
\hline $\begin{array}{c}\text { Taxonomic } \\
\text { classification }\end{array}$ & Synonym & Common names \\
\hline Kingdom: Plantae & Pinus longifolia & $\begin{array}{c}\text { English: Long leaved Pine or chir } \\
\text { pine }\end{array}$ \\
Division: Pinophyt & Hindi: Chil, Chir, Salla \\
Class: Pinopsida & Sanskrit: Manojna \\
Order: Pinales; & Gujrati name: Teliyodeodaro \\
Family: Pinaceae & Bengali: Saralgachhai \\
Genus: Pines & Malyalam: Salla, Charalam \\
Subgenus: Pines & Tamil :Simaidevadari \\
Species: roxburghii & Telgu: Devadaru \\
\hline
\end{tabular}

\section{Table 2: Bioactive constituents in Pinus roxburghii.}

\begin{tabular}{|c|c|}
\hline Part of plant & Bioactive constituents \\
\hline $\begin{array}{l}\text { Needle essential } \\
\text { oil }^{14,15}\end{array}$ & $\begin{array}{c}\alpha \text {-Pinene }(22.8 \%), \text { camphene }(0.4 \%), \beta \text {-pinene }(14.1), \Delta 3 \text { - } \\
\text { carene }(50.6 \%), \alpha \text {-phellandrene }(0.1 \%), \alpha \text {-terpinene }(0.4 \%), \\
\text { limonene }(0.9 \%), \beta \text {-phellandrene }(0.7 \%), \gamma \text {-terpinene } \\
(0.5 \%), p \text {-cymene }(\operatorname{tr}), \text { longipinene }(0.2 \%), \text { cyclosativene } \\
\text { (tr), sativene }(0.1 \%), \text { longifolene }(3.4 \%), \beta \text {-caryophyllene } \\
(0.2 \%), \alpha \text {-terpeinyl acetate }(0.3 \%), \text { longicyclene }(0.2 \%), \\
\text { terpinolene }(3.8 \%), \text { reported in resin. Zafar } \text { et al } \\
2010 \text { reported } \alpha \text {-Pinene }(29.3 \%), \beta \text {-myrcene }(1.1 \%), \\
3 \text {-carene ( } 14.2 \%) \text {, terpinyl acetate }(1.0 \%), \alpha \text {-terpineol } \\
\text { (4.5\%), borneol acetate }(2.2 \%), \alpha \text {-longipinene }(1.2 \%), \\
\text { caryophyllene (21.9\%) and caryophyllene oxide }(3.1 \%) \text { in } \\
\text { needle essential oil. } \\
\text { Caryophyllene, } 3 \text { Carene, Alpha humulene, alpha pinene, } \\
\text { Beta pinene, alpha terpineol, Car-3-ene, Longifolene, } \\
\text { camphene, limonene, alpha ternene, alpha terpineol, alpha } \\
\text { borneol. }\end{array}$ \\
\hline $\begin{array}{l}\text { Wood essential } \\
\text { oil }^{13}\end{array}$ & $\begin{array}{c}\text { Caryophyllene (16.75), Thunbergol(16.29), } 3 \text { carene } \\
\text { (14.95\%), Cambrene(12.08\%), alpha thujene (10.81\%), } \\
\text { terpinolen (7.17\%), alpha pinene(4.8\%), alpha } \\
\text { caryophyllene (3.7\%), sabinene (3.79\%), Verticol (1.84\%), } \\
4 \text { terpineol (1.79\%), myrcene }(1.28 \%)\end{array}$ \\
\hline $\begin{array}{l}\text { Bark essential } \\
\text { oil }^{13}\end{array}$ & $\begin{array}{l}\text { alpha pinene( } 31.29 \%), 3 \text { carene }(28.05 \%) \text {, } \\
\text { Cambrene( } 4.86 \%) \text {, Longifolene (4.42\%), Thunbergol(4.11), } \\
\text { beta pinene }(2.99 \%) \text {, sylbestrene }(2.4 \%) \text {, terpineol }(2.05 \%) \text {, } \\
\text { terpinolen }(2.03) \text {, terpinyl acetate(1.56\%), elemol( } 1.46 \%) \text {, } \\
\text { Methyl dihydro abtate }(1.3 \%) \text {, myrcene }(1.36 \%) \text {, Bornyl } \\
\text { acetate }(1.1 \%) \text {, alpha cadinol }(1.08 \%)\end{array}$ \\
\hline $\begin{array}{l}\text { Stem and needle } \\
\quad \text { extract }^{14,16}\end{array}$ & $\begin{array}{l}\text { Quercetin, resin acid (abietic acid, neoabietic acid), } \\
\text { taxifolin, catechin, quercetin derivative, taxifolin } \\
\text { derivative, catechin and gallocatechin, kaempferol, } \\
\text { rhamnetin isorhamnetin, myricetin, 3,4-dihydroxybenzoic } \\
\text { acid, 3,4-dihydroxycinnamic acid, monomethyl } \\
\text { pinosylvin, dihydromonomethyl pinosylvin, resveratrol, } \\
\text { glycoside, pinoresinol, secoisolariciresinol. }\end{array}$ \\
\hline $\begin{array}{l}\text { Petroleum ether } \\
\quad \text { extract }{ }^{17}\end{array}$ & Friedelin, ceryl alcohol and $\beta$-sitosterol \\
\hline \multirow[t]{2}{*}{ Bark $^{17,18}$} & $\begin{array}{l}\text { 1,5-diliydroxy-3,6,7-triniethoxy-8-allyloxyxanthone, } \\
\text { 1-hydroxy-3,6-diinethoxy-2- } \beta \text { glucopyranoxanthone, } \\
\text { friedelin, ceryl alcohol, b-sitosterol, taxifolin, quercetin, } \\
\text { catechin, kaempferol, rhamnetin, 3,4-dihydroxybenzoic } \\
\text { acid, 3,4-dihydroxycinnamic acid, pinosylvin, pinoresinol, } \\
\text { resin acid, sterols, gallocatechin and tannins }\end{array}$ \\
\hline & Hexacosylferulate \\
\hline $\begin{array}{l}\text { P. roxburghii } \\
\text { needles wax }{ }^{19}\end{array}$ & $\begin{array}{l}\text { 12-hydroxydodecanoic acid, 14-hydroxytetradecanoic acid } \\
\text { and 16- hydroxy-hexadecanoic acid }\end{array}$ \\
\hline
\end{tabular}

and in gonorrhea. The bark has tannins used for coloring the leather. Leaves are used in construction of roofs as "Channana". The needles of Pinus roxburghii are ground and mixed with water and given to patients suffering from measles. The oil obtained by the distillation of the needles is used in muscular pains and as expectorant. ${ }^{25}$ The seeds from the female cones are edible and are consumed in treatment of bronchitis, tuberculosis and urinary bladder infections. ${ }^{25}$

\section{Commercial uses}

Pinus roxburghii is majorly a timber yielding plant and hence possess high commercial value. The heartwood of the plant is used in the making of furniture and building houses while the softwood is used in packaging cases and tea chest. ${ }^{26}$ The bark is rich in tannins and finds its application in tanneries. The resin is commonly used to repair broken ceramic 


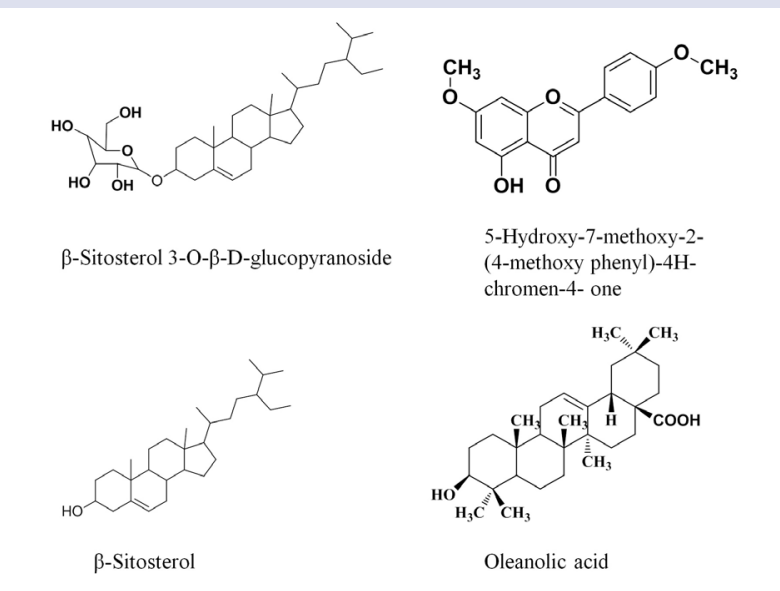

Figure 1a: Structure of different bioactive compounds from Turpentine oil of Pinus roxburghii.

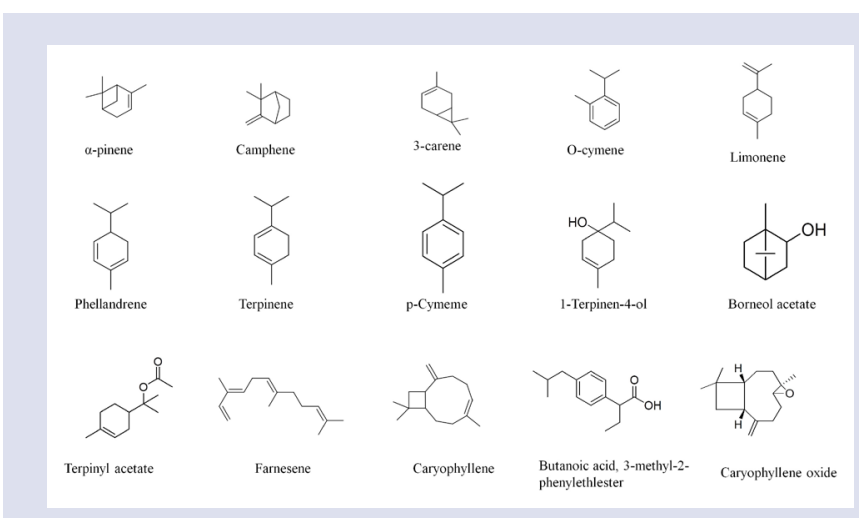

Figure $1 \mathrm{~b}$ : Structure of different bioactive compounds from Pinus roxburghii Needles.

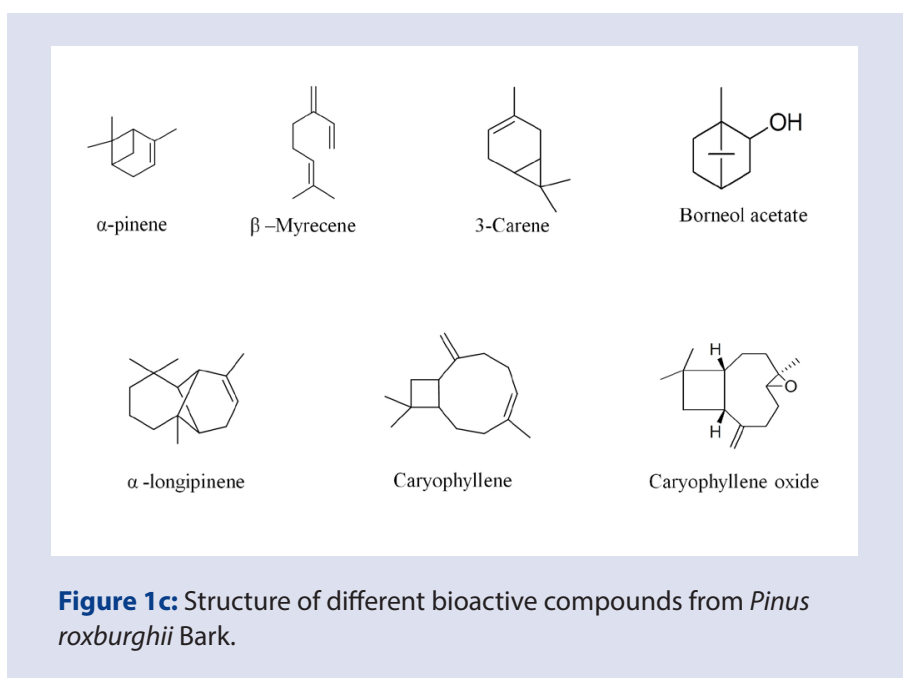

pottery. It is also used in protective coatings, varnishes and printing ink. When destructively distilled, resin produces a viscous liquid called rosin oil which is used as lubricating greases. ${ }^{27}$ Turpentine oil is commercially important as it is a major component in varnishes, thinners, sealing wax, soaps and disinfectants. ${ }^{27}$

\section{Pharmacological uses Hepatoprotective Activity}

Imran et al, 2012 studied hepatoprotective activity of wood oil of Pinus roxburghii at doses of 200, 300 and $400 \mathrm{mg} / \mathrm{kg}$ on rat liver damage induced by carbon tetrachloride and ethanol. The substantially elevated enzymatic levels of aspartate aminotransferase, alanine aminotransferase, alkaline phosphatase and decreased level of reduced glutathione (GSH) and total protein were significantly restored to normal levels. ${ }^{10}$

\section{Analgesic and Anti-inflammatory Activities}

Alcoholic extract of Pinus roxburghii bark exhibited anti-inflammatory and analgesic activityat the doses of 100, 300 and $500 \mathrm{mg} / \mathrm{kg}$ (analgesic activity was evaluated by acetic acid-induced writhing and tail immersion tests in swiss albino mice. Acute and chronic anti-inflammatory activity was evaluated by carrageenan-induced paw oedema and cotton pellet granuloma in wistar albino rats. These activities were due to the presence of polyphenolic compounds present in the extract. ${ }^{28}$

\section{Anticonvulsant Activity}

Kaushik et.al., 2012 reported alcoholic extract of Pinus roxburghii extract at doses of 100, 300 and $500 \mathrm{mg} / \mathrm{kg}$ was effective against generalized tonic-clonic and partial seizures using maximal electroshock induced seizure model in rats. ${ }^{29}$

\section{Antiasthmatic activity}

The alcoholic extract of $P$. roxburghii was evaluated as antiasthmatic using guinea pig ileum preparation (in-vitro), histamine-induced bronchospasm in guinea pigs and catalepsy in mice (in-vivo). Anti-allergic activity of the plant was evaluated using milk-induced leukocytosis in mice and passive paw anaphylaxis in rats (in-vivo). ${ }^{30}$

\section{Antioxidant and Antidyslipidemic Activities}

Pinus roxburghii needle extract possesses significant potential to lower the level of plasma lipid profile followed by a beneficial effect on high density lipoproteins (HDL) in high fat diet fed hyperlipidemic golden Syrian hamster model. Antioxidant activity of n- butanol fraction and alcoholic extract was found to be significant when assessed by trolox equivalent antioxidant capacity (TEAC) assay. Sharma et.al., 2016 described plant extract of Pinus roxburghii bark posses significant antioxidant activity against 2,2-diphenyl-1-picrylhydrazyl (DPPH) and nitric oxide assays. ${ }^{11,31}$

\section{Anticancer activity}

Petroleum ether, ethyl acetate, chloroform and ethanol extract of Pinus roxburghii Sarg. was evaluated for anticancer activity on IMR-32 Human Neuroblastoma cancer cell line and implicit the observation that petroleum ether and Chloroform extracts having promising activity. Cone essential oil of $P$. roxburghii showed notable cytotoxic activity on MCF-7cells at $100 \mu \mathrm{g} / \mathrm{ml}^{32,33}$

\section{Antibacterial Activity}

The plant extract shows the antimicrobial potential against a wide variety of microorganisms. Bissa et.al., 2008 studied antibacterial activity of aerial parts of Pinus roxburghii against E.coli, Enterobacter aerogenes, Agrobacterium tumefaciens. ${ }^{25}$ Sharma et. al., 2016 reported significant antimicrobial 
activity of Pinus roxburghii bark extract against Pseudomonas aeruginosa, Escherichia coli, Staphylococcus aureus and Candida albicans and promising antifungal activity against Candida albicans ${ }^{31}$ Aqueous and alcoholic extracts from $P$. roxburghii stem, leaves, bark, female cone and male cone showed growth-inhibitory activity against the bacterial plant pathogen Agrobacterium tumefaciens. ${ }^{34}$

\section{Antidiabetic activity}

Ethanolic extract of Pinus roxburghii bark at dose of 100, 300, $500 \mathrm{mg} / \mathrm{kg}$ possesses significant antidiabetic activity in alloxan-induced-diabetic rats. ${ }^{35}$ In an in-silico study by Kaushik et. al., 2014, it was observed that secoisoresinol, pinoresinol, and cedeodarin showed the best docking results on different diabetic receptors. ${ }^{36}$ In an another study Kaushik et. al., 2015 showed that the extracts from the bark of Pinus roxburghii by bioassay guided fractionation have good antidiabetic activity when tested through $\alpha$-amylase inhibitory assay in-vitro. ${ }^{37}$

\section{Pinus gerardiana \\ Habitat and morphology}

Pinus gerardiana, known as the chilgoza pine, (noosa, or neoza) is a pine native to the northwestern Himalayas. There are about 29 species of pine which produce edible nuts those are utilized by indigenous tribal cultures in the world. In India, out of six species of pine, Pinus gerardiana is the only species which produces edible and highly nutritious nuts. ${ }^{38}$ This species is distributed not only in India but also in Afghanistan, Tibet, Baluchistan (Pakistan) between 2000 and 3350 m elevation..$^{39,40,41}$ In India, it is distributed only in Himachal Pradesh (Kinnaur and Chamba Districts) and Jammu and Kashmir.

The branches are slightly ascending, and usually not whorled. The bark exfoliates in irregular thin flakes, gray in colour. The leaves are needle like, stiff, dark green, and are arranged in clusters of three. Male cones are long, and female cones are oblong ovoid with thick woody scales. Seeds are cylindrical, elongated, dark brown pointed at the tip, measure and bear a rudimentary wing. Pinus gerardiana is well known for its edible seeds (Chilgoza), rich in carbohydrates and proteins. These "nuts" are known and sold locally under the name of Chilgoza, "Neja" (singular) or "Neje" (plural). Chilgoza is only pine which is of immense social forestry importance because it is an income source for tribal peoplein the Kinnaur district of Himachal Pradesh. ${ }^{42}$ They are either eaten raw or roasted and are also included as an ingredient in a variety of traditional dishes, such as breads, candies, sauces and cakes, as well as in vegetable and meat dishes. In general, pine nuts are known to be a good source of nutrients. Taxonomy and common names of Pinus gerardiana are given in Table 4

\section{Phytochemical constituents}

The nuts are considered to be rich source of various nutrients including proteins, carbohydrates, fibers, minerals besides its higher amount of oil. Its oil is of very good quality, free of cholesterol and a rich source of fatty acids like Stearic acid (0.3\%), Linoleic acid (Omega-6) (51.3\%), Linolenic acid (Omega-3) (1.5\% ) Oelic acid (Omega-9) (39.7\% Arachidic acid (2.1\%) Palmitic acid (7.2\%). ${ }^{43}$ Hoon et. al., 2014, reported approximately $50 \%$ fat, $30 \%$ protein, $10 \%$ carbohydrate, $4 \%$ ash and $6 \%$ moisture in Pine nuts. ${ }^{44}$ The seeds with edible kernels are obtained from ripe cones credited with carminative stimulant and expectorant properties. Analysis of kernels possesses delicate terbinthine flavor, moisture $(7.5 \%)$, protein (15.9\%), fat (49.9\%), carbohydrates (21.6\%), fibre (2.2), and mineral matter (2.9\%). On pressing kernels yielded a transparent clear oil having pale yellow. Low molecular weight components in pine nuts from Pinus pinea includes glucose, fructose, sucrose, and raffinose, several soluble carbohydrates, saccharides (galactose, maltose, and planteose) and cyclitols (pinitol, galactinol, galactopinitol A1, fagopyritol B1, and other glycosylinositols). Most abundantly found cyclitols are chiroinositol, fagopyritol B1, and pinitol. ${ }^{45}$ Structure of different bioactive compounds from Pinus gerardiana are shown in Figure 3.

\section{Ethnopharmacological uses}

The cones and wood are used as timber and firewood. Branches are commonly used as roof thatching materials in houses. Wood is also used as building material and making of huts and wooden boxes. ${ }^{46}$ The bark of the tree is made into baskets and also into rough buckets forfetching water. $^{47,48}$ Tan or green dye is obtained from the needles. The needles contain a substance called terpene, released when rain washes over the needles and it has a negative effect on the germination of some plants, including wheat. ${ }^{49,50}$ The resins are obtained by tapping the trunk, or by destructive distillation of the wood. Turpentine consists of an average of $20 \%$ of the oleoresin separated by distillation. Turpentine has a wide range of uses, including as a solvent for waxes etc, for making varnishes.

Table 3: Pharmacological activities of Pinus roxburghii.

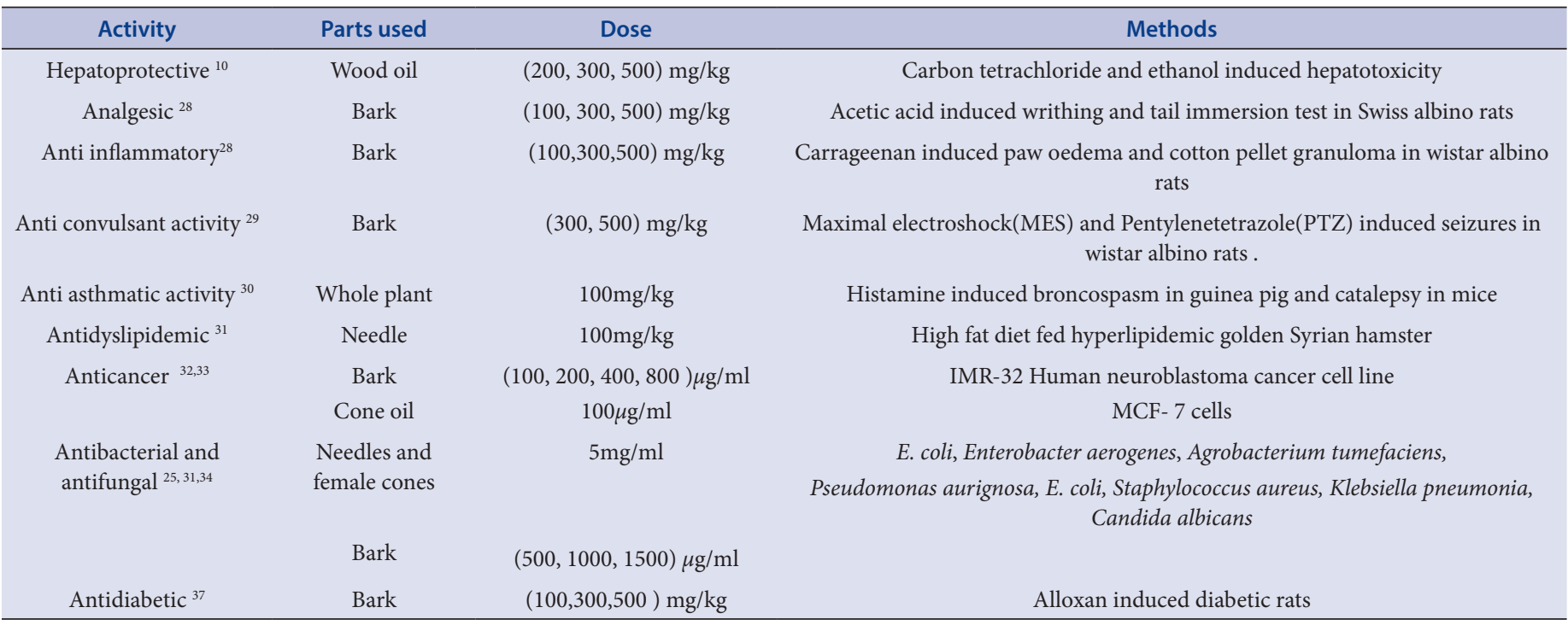


Table 4: Taxonomy of Pinus gerardiana.

\begin{tabular}{lll}
\hline Taxonomic classification & \multicolumn{1}{c}{ Synonym } & \multicolumn{1}{c}{ Common names } \\
\hline Kingdom: Plantae & Pinus gerardii & $\begin{array}{l}\text { English :Gerrard's } \\
\text { Pine, Chilgoza Pine }\end{array}$ \\
Division: Pinophyt & Hindi: Chilgoza, \\
& Neoza \\
Class: Pinopsida & Sanskrit: \\
& Dhanu,priyalam \\
Order: Pinales; & Gujrati name: Chaolli \\
Family: Pinaceae & Bengali: Chirongi \\
Genus: Pinus & Malyalam: Mungaper \\
Subgenus : & Tamil:Sarra payer \\
Ducampopinus & \\
Species: Pinus & Telgu: Morrihettu \\
gerardiana &
\end{tabular}

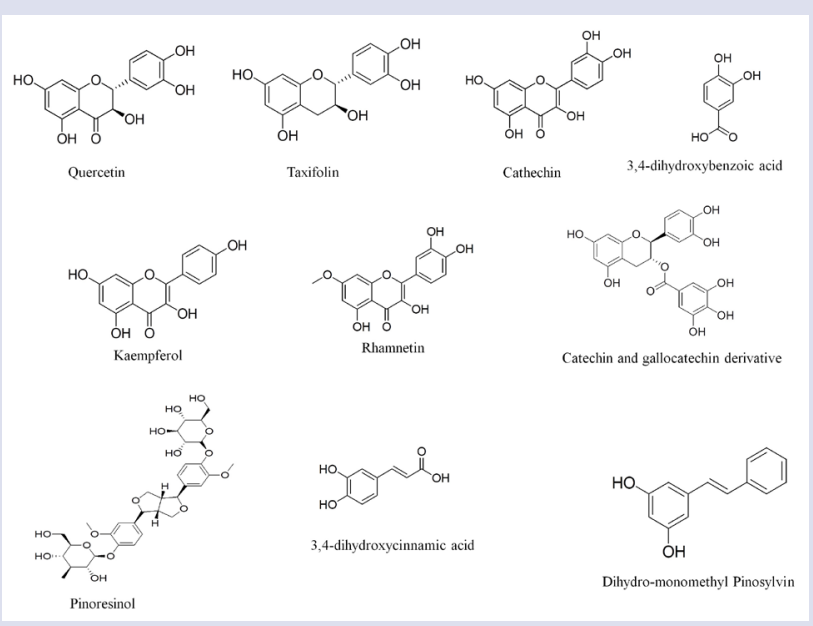

Figure 2: Structure of different bioactive compounds from Pinus wallichiana.

Rosin is the substance left after turpentine is removed. This is used by violinists on their bows and also in making sealing wax, varnish etc. Pitch can also be obtained from the resin and is used for waterproofing, as a wood preservative etc. ${ }^{51}$ Chilgoza is considered as one of the important dry fruits of the tribal area having carminative, stimulant and expectorant properties.

\section{Commercial uses}

The main economic use is its edible, oil-rich seeds (neoza in Hindi), which are harvested by knocking the cones from the trees in autumn and during early winter. The Chilgoza pine on tapping yield oleoresin of good quality, but owing to its limited availability and avoidance of destruction of trees for obtaining most valuable seeds the species has not been exploited commercially for timber. In traditional systems, sufficient cones are usually left on the tree to ensure that some seed is available for natural regeneration. ${ }^{42}$

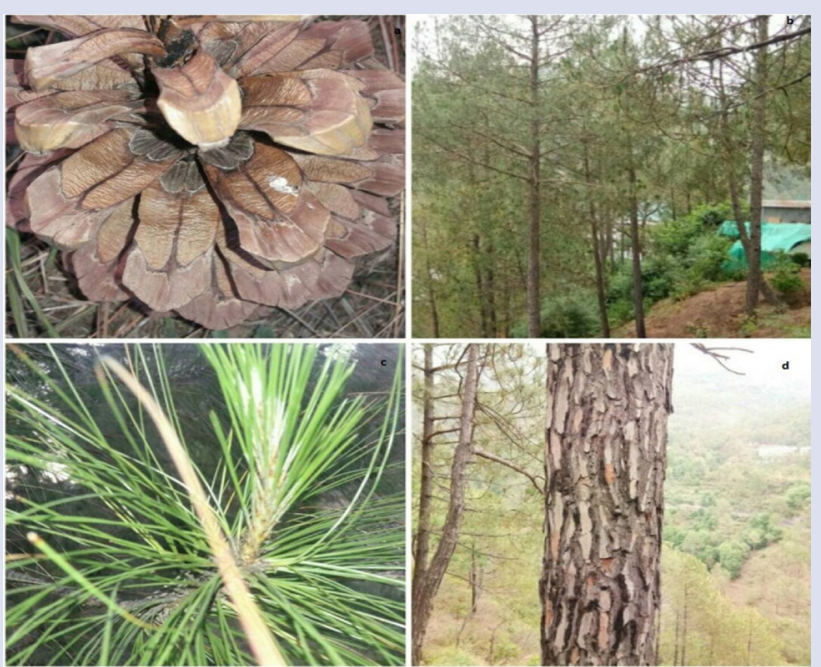

Figure 3 : Pinus roxburghii (Chir Pine) a) Cone b) Tree c) Needles d) Trunk.

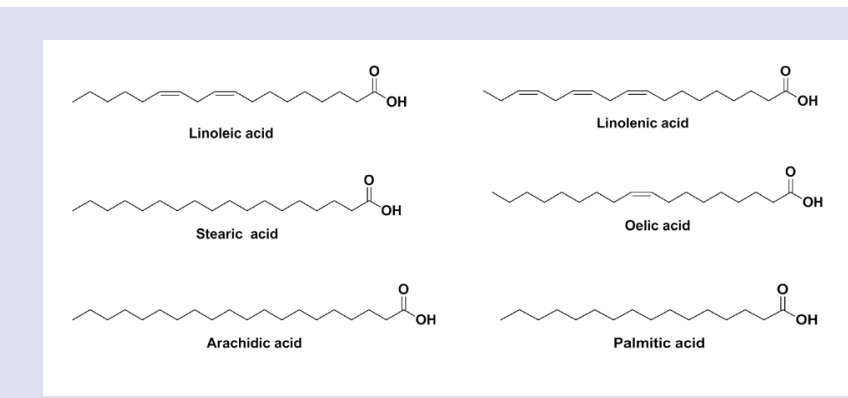

Figure 4: Structure of different bioactive compounds from Pinus gerardiana

\section{Pharmacological uses}

\section{Antioxidant assay}

Hoon et. al. 2014, studied total antioxidant capacity and the presence of antioxidant compounds in Pinus gerardania. Antioxidant compounds such as gallocatechin, catechin, lutein, lycopene, caretenoids and tocopherols are present in P. gerardania. Gallocatechin had the highest presence out of all the compounds. ${ }^{44}$ Sharma et. al. 2016, revealed the presence of various biochemical compounds such as alkaloids, flavonoids, glycosides, triterpenoids and saponins in P. gerardania. Quantitative phytochemical analysis of plant extracts showed the presence of phenolics, flavonoids, tannins, beta-carotene and lycopene. Bark extract showed significant antioxidant activity against $\mathrm{DPPH}$, nitric oxide and $\mathrm{H}_{2} \mathrm{O}_{2}$ free radicals scavenging assays. ${ }^{31}$

\section{Cardiovascular disorders and thromboembolism}

P. gerardiana nut oil caused blood clot lysis in-vitro, in vitro whole blood coagulation was also seen reduced. P. gerardiana nut oil has no effect on blood cell indices in-vivo. It was found effective in treatment of cardiovascular disorders and thrombo embolism. ${ }^{52}$ 
Table 5: Pharmacological activities of Pinus gerardiana.

\begin{tabular}{cccc}
\hline Activity & Parts used & Dose & Methods \\
\hline Antioxidant assay ${ }^{31,44}$ & Chilgoza & $(62.5,125,250,500,1000) \mathrm{mg} / \mathrm{kg}$ & DPPH, ABTS, radical cation scavenging assay. \\
Cardiovascular disorders and & Nuts oil & $30 \mu \mathrm{l} / \mathrm{ml}, 60 \mu \mathrm{l} / \mathrm{ml}$ & $\begin{array}{c}\text { Fibrinolytic activity, } \\
\text { thromboembolism }{ }^{52}\end{array}$ \\
${ }^{\text {Antiinflamatory }}{ }^{31}$ & Bark & $500,1000,1500,2000,2500 \mu \mathrm{g} / \mathrm{ml}$ & HRBC membrane stabilization assay, Albumin denaturation assay \\
Antimicrobial assay $^{31}$ & Bark & $500,1000,1500 \mu \mathrm{g} / \mathrm{ml}$ & S. aureus, E. coli, P. aeruginosaand K. pneumonia, Candida albicans \\
\hline
\end{tabular}

Table 6 : Taxonomy of Pinus wallichiana.

\begin{tabular}{ccc}
\hline $\begin{array}{c}\text { Taxonomic } \\
\text { classification }\end{array}$ & Synonym & Common names \\
\hline Kingdom: Plantae & Pinus excels & Botanical name: Pinus wallichiana \\
Division: Pinophyta & Pinus griffithii & English :Himalayan pine \\
Class: Pinopsida & Pinus chylla & Hindi: Kail \\
Order: Pinales; & & Kashmir Yiro, kail,kaiar \\
Family: Pinaceae & Bhutan TongschiLamshing \\
Genus: Pinus & German :Tranenkiefer \\
Subgenus :Strobus & \\
Species: Pinus & \\
wallichiana & \\
\hline
\end{tabular}

\section{Antiinflammatory activity}

Hydroalcoholic extract of $P$. gerardiana stem bark at 500, 1000, 1500, 2000, $2500 \mathrm{ug} / \mathrm{ml}$ showed in-vitro anti-inflammatory activity, carried out using albumin denaturation and HRBC membrane stabilization assays. ${ }^{31}$

\section{Antimicrobial and antifungal activity}

Hydro-alcoholic extract of P.gerardiana at 500, 1000, $1500 \mathrm{ug} / \mathrm{ml}$ possessed potent antibacterial activity against Gram positive (S. aureus) and Gram negative (E. coli, P. aeruginosaand K. pneumoniae) bacteria and showed prominent antifungal activity against Candida albicans. ${ }^{31}$

\section{Pinus wallichiana}

\section{Habitat and morphology}

Pinus wallichiana (Bluepine/Kail), is coniferous evergreen tree native to Himalayas, Karakoram and Hindu Kush mountains from eastern Afghanistan, east across northern Pakistan and India. The species grows naturally along the entire length of temperate Himalayas usually at altitudes ranging 2000 to 3,500 meter above mean sea level. ${ }^{53}$ Tree is $50+\mathrm{m}$ tall with straight trunk and short downcurved branches. Branches longer in solitary trees, creating a dome-like crown. ${ }^{40}$ Bark is smooth and resinous in young stems, turning grey and corky with shallow fissures on mature trees with height of $36 \mathrm{~m}$. Bluish green leaves are needle like and are in clusters of five, $10-20 \mathrm{~cm}$ long, cones are light brown and when ripe are very resinous and easily distinguishable from other pines. Female cones are in groups of 1-6, 20-30 cm long, erect when young but later pendant, bluish-green when young, maturing to light brown with pale brown apophyses. ${ }^{40}$ Of the Indian pines, it is the finest pines of north-western Himalayan region, is well known for its commercial and ecological importance, the wood of the blue pine is considered to be the best and stands next to deodar in value. ${ }^{54,55,56}$ Though exploited mainly as a source of timber, the species is good source of oleoresin also, which is used for the production of turpentine oil, rosin, needle oil and camphor ${ }^{57,58}$ Taxonomy and common names of Pinus wallichiana are shown in Table 6:
Table 7: Bioactive constituenets in Pinus wallichiana.

\begin{tabular}{|c|c|}
\hline Plant part extract & Bioactive constituents \\
\hline \multirow[t]{2}{*}{ Needle extract ${ }^{59}$} & Quercetin $(21.426 \%)$, Isorhamnetin $(2.857 \%)$ \\
\hline & $\begin{array}{c}\beta \text {-sitosterol, } \beta \text {-sitosterol-3-O- } \beta \text {-d- } \\
\text { glucopyranoside,5-hydroxy-7-methoxy-2-(4- } \\
\text { methoxyphenyl)-4H-chromen-4-one, Oleanolic } \\
\text { acid }\end{array}$ \\
\hline $\begin{array}{l}\text { Stem bark methanolic } \\
\text { extract }^{60}\end{array}$ & $\begin{array}{c}\text { Kampherol (2.300\%), Rhamnetin (2.08\%), } \\
\text { Myrcetin (3.0\%), Isorhamnetin (2.005\%), } \\
\text { Quercetin (5.009) }\end{array}$ \\
\hline Turpentine ${ }^{61}$ & $\begin{array}{c}\text { a-pinene(90\%), Abietic and isopimaric acid, } \\
\text { lambertianic acid. }\end{array}$ \\
\hline
\end{tabular}

\section{Traditional and commercial uses}

Many species of Pinus yield valuable timber used for making furniture, door, window frames, paper pulp. ${ }^{42}$ The wood is moderately hard, durable and highly resinous. It is a good firewood but gives off a pungent resinous smoke. Pine timber is divided in hard pines of two or three needled species and soft pine of five needled species. In India $P$. wallichiana (Kail) and Pinus roxburghii yield commercial timber. It is a commercial source of turpentine which is superior quality than that of $P$. roxburghii but is not used so freely. ${ }^{42}$ It is of similar timber properties and quality to P. strobus and P. monticola in North America, with tall, straight trees producing wood of good strength.

\section{Phytoconstituents}

Sharma et. al., 2016, reported the presence of alkaloids, flavonoids, tannins, phenols, lycopene and carotenoids in hydroalcoholic extracts of Pinus wallichiana stem bark extract. ${ }^{31}$ Presence of other constituents are shown in Table 7. Structure of different bioactive compounds are given in Figure 5.

\section{Pharmacological Activities \\ Antimicrobial activity}

Sharma et. al., 2015 reported hydroalcoholic needle extract of Pinus wallichiana have significant antibacterial activity against $P$. aeruginosa and E. coli. Hydroalcoholic stem bark extract of Pinus wallichiana possess significant antibacterial activity against Pseudomonas aurignosa, S. aureus, K. pneumonia and possesses potent antifungal activity against Candida albicans. ${ }^{31}$ In another study by Rahman et. al., 2016 Pinus wallichiana showed potent antibacterial and antifungal activity against Escherichia coli, Bacillus subtilis, Shigella flexenari (clinical isolate), Staphylococcus aureus, Pseudomonas aeruginosa and Salmonella typhi, the fungal strains were Trichophyton longifusis (clinical Isolate), Candidaalbicans, Aspergillus flavus, Microsporum canis and Candida glaberata. ${ }^{62}$ 


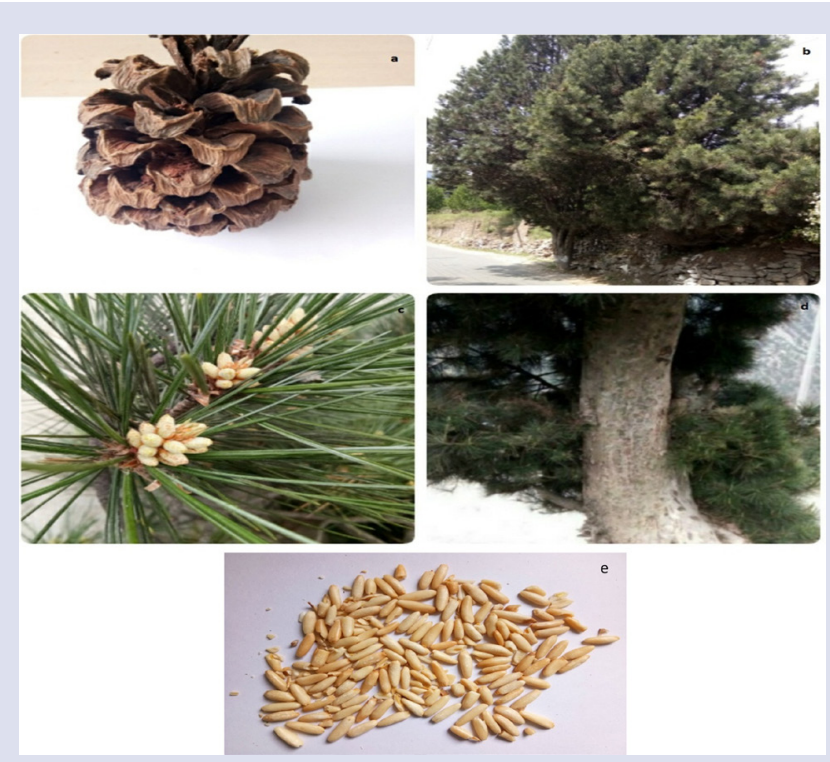

Figure 5: Pinus gerardiana (Chilgoza pine)a) Cone b) Tree c) Needles d) Trunk e) Kernels
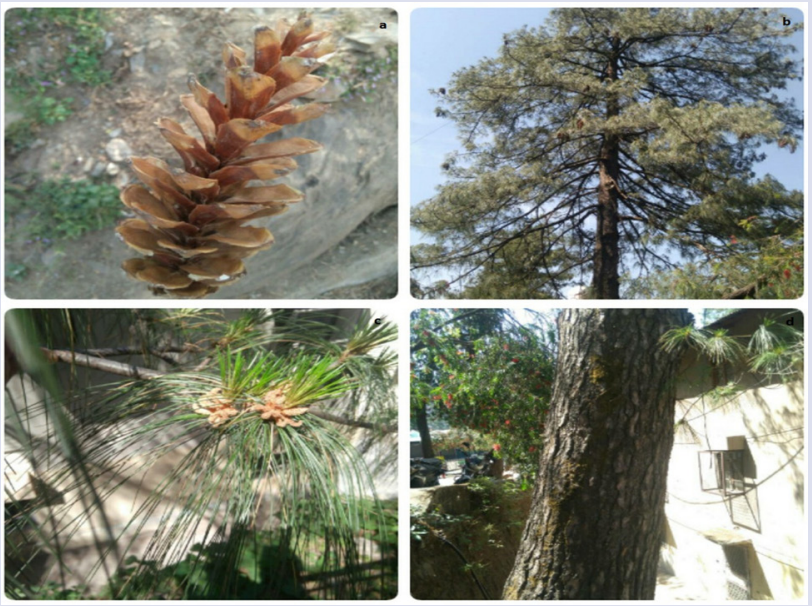

Figure 6: Pinus wallichiana (Blue Pine) a) Cone b) Tree c) Needles d) Trunk.

\section{Insecticidal assay}

Different fractions of Pinus wallichiana extract were tested against various insects Rhyzopertha dominica, Tribolium castaneum and Callosobruchus analis. The The $n$-hexane fraction showed $20 \%$ activity against $R$. dominica, while the ethyl acetate showed $20 \%$ activities against all the strains. The chloroform revealed $20 \%$ activity against $R$. dominica, while the aqueous showed $20 \%$ and $40 \%$ activity against $R$. dominica and C. analis. ${ }^{60}$

\section{Phototoxic activity}

The $n$-hexane, ethyl acetate, chloroform, aqueous fractions of Pinus wallichiana needles showed significant phytotoxicity activity at $500 \mu \mathrm{g} / \mathrm{ml}$, while at low concentration $50 \mu \mathrm{g} / \mathrm{ml}$ and $5 \mu \mathrm{g} / \mathrm{ml}$ showed moderate activity. ${ }^{60}$

\section{Antioxidant activity}

Hydroalcoholic extract of leaves and stem bark of Pinus wallichiana possess significant in-vitro antioxidant activity when tested in DPPH,
Table 8: Pharmacological activities of Pinus wallichiana.

\begin{tabular}{|c|c|c|c|}
\hline Activity & Parts used & Dose & Methods \\
\hline $\begin{array}{l}\text { Antimicrobial } \\
\text { activity }^{60,62}\end{array}$ & Needles & $24 \mathrm{mg} / \mathrm{ml}$ & $\begin{array}{l}\text { Agar well diffusion } \\
\text { method }\end{array}$ \\
\hline $\begin{array}{l}\text { Insecticidal } \\
\text { activity }^{60}\end{array}$ & Needles & $20 \mathrm{mg} / \mathrm{kg}$ & $\begin{array}{l}\text { Insects: Rhyzopertha } \\
\text { dominica, Tribolium } \\
\text { castaneum and } \\
\text { Callosobruchus analis. }\end{array}$ \\
\hline Antioxidant ${ }^{31}$ & Bark & $\begin{array}{c}(10,20,40,80,100) \\
\mu \mathrm{g} / \mathrm{ml}\end{array}$ & $\begin{array}{l}\text { DPPH, Nitric oxide } \\
\text { and Hydroxyl radical } \\
\text { scavenging assay }\end{array}$ \\
\hline $\begin{array}{c}\text { Anti } \\
\text { inflammatory }\end{array}$ & Bark & $\begin{array}{l}(500,1000,1500, \\
2000,2500) \mu \mathrm{g} / \mathrm{ml}\end{array}$ & $\begin{array}{l}\text { Albumin denaturation, } \\
\text { HRBC membrane } \\
\text { stabilization }\end{array}$ \\
\hline
\end{tabular}

Table 9: Marketed formulation of Pinus species.

\begin{tabular}{ccc}
\hline Name of formulation & Plant part used & Pharmacological activity \\
\hline${\text { Polyherbal oil extract }{ }^{63}}^{\text {Oleo resin of Pinus }}$ & $\begin{array}{c}\text { Analgesic and anti- } \\
\text { roxburghii } \\
\text { Rumalaya gel }{ }^{64,65}\end{array}$ & $\begin{array}{c}\text { Resin from Pinus } \\
\text { roxburghii }\end{array}$ \\
& $\begin{array}{c}\text { Joint and Bone pain } \\
\text { associated with various } \\
\text { orthopedic ailments }\end{array}$ \\
\hline
\end{tabular}

nitric oxide radical scavenging, hydroxyl radical scavenging and hydrogen peroxide radical scavenging assays. Presence of phenolics, flavonoids, tannins, carotene were also reported in Pinus wallichiana. ${ }^{62,31}$

\section{Anti-inflammatory activity}

Hydroalcoholic stem bark extract of Pinus wallichiana possesses significant in-vitro anti-inflammatory activity when tested through albumin denaturation and $\mathrm{RBC}$ membrane stabilization assays. ${ }^{31}$

\section{Marketed formulations}

A summary of commercial formulations of Pine species is given in Table 9.

\section{CONCLUSION}

This review furnishes the presence of several phytochemical components and pharmacological properties of Pinus roxburghii, Pinus wallichiana and Pinus gerardiana. The pharmacological activities reported in the present review confirm that the therapeutic value of these plants is very high, having a leading capacity for the development of a new, safe, effective and cheaper drug in future. But there is need for more elaborative study, pharmacological investigations, clinical trials, more exploration and public awareness for the best utilization of medicinal properties of these pine species. Even the industrial entrepreneurs also should come forward with new concepts and steps towards the best use of these potential medicinal pine species. Lets hope that in future herbal products will be competing modern medicines with added advantages of more safety and lower costs.

\section{CONFLICT OF INTEREST}

The authors have declared no competing interest.

\section{ABBREVIATIONS}

HDL: High Density Lipoprotein; DPPH: 2,2,diphenyl picrylhydrazyl; TEAC: Trolox equivalent antioxidant activity; ABTS: 2,2'-azino-bis(3ethylbenzothiazoline-6sulphonic acid. 


\section{REFERENCES}

1. Craker LE, Janick J, Whipkey A. Medicinal and aromatic plant future opportunities. Issues in New Crops and New Uses. ASHS Press. 2007;248-57.

2. Aggarwal SG. Antibacterial activity of plants of Himalayan region. World journal of pharmacy and Pharmaceutical Sciences. 2014;3(5):581-7.

3. Richardson DM, Rundel PW, Jackson ST, Teskey RO, Aronson J, et al. Human impacts in pine forests: past. Annual Review of Ecology and Systematic. 2007;38:275-97.

4. Little EL, CritchfieldWB. Subdivisions of the Genus Pinus. USDA Forest Service Miscellaneous Publication. 1969

5. Gamble JS. A Manual of IndianTrees. Sampson Low, Marston and Co. London. 1902.

6. Sharma RN, Bala J, Singh A, Prabhjot K. Antibacterial Potential of Achyranthusaspera Linn procured from Himachal Pradesh, Punjab and Haryana, India. Research Journal of Chemical Sciences. 2011;(8):80-2.

7. Samant SS, Pant S, Singh M, Lal M, Singh A, Sharma A, et al. Medicinal plants in Himachal Pradesh, north western Himalaya, India. Inter. Jour. of Biodiversity Sci. and Management. 2007;3(4):234-51.

8. Chauhan PK, Sharma S, Chandrika, Harsh, Manisha, Mansi. Evaluation of Phytochemical and in-vitro Antioxidant and antibacterial activities of Wild plant species of Bauhinia and Ficus of HP. World Journal of Pharmacy and Pharmaceutical sciences. 2014;3(4):659-68.

9. Shuaib M, Ali M, Ahamad J, Naquvi KJ, Ahmad MI. Pharmacognosy of Pinus roxburghii: A Review. Journal of Pharmacognosy and Phytochemistry. 2013;2(1):262-8.

10. Puri A, Anuj K, Singhal B, Mishra SK, Srivastava S, Lakshmi V. Antidyslipidemic and antioxidant activity of Pinus roxburghii needles. Med Chem. Res. 2011;(20):1589-93

11. Khan I, Singh V, Chaudhary AK. Hepatoprotective activity of Pinus roxburghi Sarg. wood oil against carbon tetrachloride and ethanol induced hepatotoxicity. Journal of the Bangladesh Pharmacological Society (BDPS). 2012;(7):94-9.

12. Kirtikar KR, Basu BD. Indian Medicinal Plants, 2nd Ed., International Book Distributors, Dehradun. 1999;2385-88.

13. Kaushik P, Kaushik D, Khokra SL. Ethnobotany and phytopharmacology of Pinus roxburghii Sargent: A plant review. J Integr Med. 2013;11(6):371-6.

14. Coppen JJ, Robinson JM, Kaushal AN. Composition of xylem resin from Pinus wallichiana and P roxburghii. Phytochemistry. 1988;27(9):2873-5.

15. Swales M, Devi L. Indian wood terpene oil, scope, production, and chemical composition. Indian Perfumer. 1979;(23):79-83.

16. Willfor S, Ali M, Karonen M, Reunanen M, Arfan M, Harlamow R. Extractives in bark of different conifer species growing in Pakistan. Holzforschung. 2009;(63)5:551-8.

17. Beri RM. Chemical constituents of the bark of Pinus roxburghii Sargent. Indian J Chem. 1970;(8):469-70.

18. Rawat U, Srivastava B, Semwal S, Sati OP. Xanthones from Pinus roxburghii. J. Indian Chem Soc. 2009;(83):391-2

19. Zafar I, Fatima A, Khan SJ, Rehman Z, Mehmud S. GC-MS studies of needles essential oil of Pinus roxburghii and their antimicrobial activity from Pakistan. Electr. J Environ Agric. Food Chem. 2010;9(3):468-73.

20. Hussain KF, Nisar M, Majeed A, Nawaz K, Bhatti KH. Ethnomedicinal Survey for Important Plants of Jalalpur Jattan, District Gujrata, Punjab, Pakistan. Ethnobotanical Leaflets. 2010;(14):807-25.

21. Bajracharya MB. Ayurvedic Medicinal Plants and General Treatments. Jore Ganesh Press Pvt Ltd: Kathmandu. 1979;78-85.

22. Chauhan NS. Medicinal and Aromatic Plants of Himachal Pradesh. Indus Publication Company: New Delhi. 1999;90-7.

23. Singh H, Saklani A, Lal B. Ethnobotanical observations on some Gymnosperms of Garhwal Himalaya, Uttar Pradesh, India Eco Botany. 1990;44(3):349-54.

24. Uniyal S, Singh KN, Jamwal P, Lal B. Traditional use of medicinal plants among the tribal communities of Chhota Bhangal. Western Himalaya. Journal of Ethnobiology and Ethnomedicine. 2006;2(1):176-84.

25. Bissa SB. Antibacterial potential of three naked-seeded (Gymnosperm) plant. Natural Product Radiance. 2008;7:420-5.

26. Rajbhandari KR Ethnobotany of Nepal. Ethnobotanical Society of Nepal, Kathmandu. 2001;189-96.

27. Manandhar NP. Plant and People of Nepal. Timber Press Inc: Portland Oregon. 2002;67-74

28. Kaushik D, Kumar A, Kaushik P, Rana AC. Analgesic and Anti-Inflammatory activity of Pinus roxburghii Sarg. Adv Pharmacol. Sci. 2012;1-6.

29. Kaushik D, Kumar A, Kaushik P. Anticonvulsant activity of alcoholic extract of bark of Pinus roxburghii Sarg. Journal of Chinese Integrative Medicine. 2012;10(9):1056-60.

30. Kaushik P, Kaushik D. Ethnobotany and phytopharmacology of Pinus roxburghii Sargent: A plant review. Journal of integrative medicine. 2013;11(6):371-6.

31. Sharma A, Goyal R, Sharma L. Potential biological efficacy of Pinus plant species against oxidative, inflammatory and microbial disorders. BMC Alternative and Complementary Medicine. 2016;6:1-11.
32. Kaushik P, Khokra SL, Rana AC, Kaushik D. Evaluation of Anticancer Activity of Pinus roxburghii Sarg. Against IMR-32 Human Neuroblastoma Cancer Cell Line. International Journal of Pharmaceutical and Clinical Research. 2015;7(1):105-8

33. Satyal P, Paudel P, Raut J, Deo A, Dosoky NS, Setzer WN. Volatile constituents of Pinus roxburghii from Nepal. Pubmed Res. 2013;5(1):43-8.

34. Parihar $P$, Parihar L, Bohra A. Antibacterial Activity of extracts of Pinus roxburghii Sarg. Bangladesh J Bot. 2006;35(1):85-6.

35. Kaushik P, Khokra SL, Kaushik D. Evaluation of antidiabetic potential of Pinus roxburghii bark extract in alloxan induced diabetic rats. J Pharmacogn Nat. Prod. 2015;2-5.

36. Kaushik , Khokra SL, Rana AC, Kaushik D. Pharmacophore modeling and molecular docking studies on Pinus roxburghii as a Target for diabetes mellitus. Advances in Bioinformatics. 2014;1-5.

37. Kaushik P, Singh G, Khokra SL, Kaushik D. Bioassay guided fractionation and $\alpha$-amylase inhibitory activity of flavanoid isolated from Pinus roxburghii Sarg. Natural Products Chemistry and Research. 2015;3(179):2.

38. Gupta BL. Forest flora of Chakrata. Dehra Dun and Saharanpur. Dehradun: Forest Research Institute Gymosperms of India II. Chilgoza pine (Pinus geraradiana Wall.) Bulletin No. 109. National Botanical Gardens: Lucknow. 1964. India.

39. Critchfield WB, Little EL. Geographic distribution of the pines of the world. USDA Forest Service Miscellaneous. USA. 1966;99.

40. Farjon A. Pines: Drawings and descriptions of the genus Pinus, Antiquarian Book sellers Association of America: New York. 1984.

41. Farjon A. World checklist and bibliography of conifers, Royal Botanical Gardens: Kew, Surrey, UK. 2001.

42. Peltier R, Dauffy V. The Chilgoza of Kinnaur. Influence of the Pinus gerardiana edible seed market chain organization on forest regeneration in the Indian Himalayas. Fruits. 2009;64(2):99-110.

43. Thakur NS, Gupta A, Chauhan VK. Studies on quality characteristics of chilgoza nut and oil. International Journal of Farm Sciences. 2015;5(1):78-82.

44. Hoon LY, Choo C, Watawana MI, Jayawardena N, WaisundaraVY. Evaluation of the total antioxidant capacity and antioxidant compounds of different solvent extracts of Chilgoza pine nuts (Pinus gerardiana). Journal of functional foods. 2015;18:1014-21.

45. Aceituno LR, Ramos L, MartinezCastro I, Sanz ML. Low Molecular Weight Carbohydrates in Pine Nuts from Pinus pinea L. J Agric Food Chem. 2012;60(19):4957-9.

46. Gamble JS. A manual of Indian Timbers. Sampson Low, Marston and Co.Ltd: London. 1902;868.

47. Gamble JS. A Manual of Indian Timbers. 1972.

48. Muhammad Ibrar FH, Ethnobotanical Profile of Gymnospermic Flora of Kalash Valley, District Chitral, Hindo-Kush Range, Pakistan American-Eurasian J Agric and Environ. Sci. 2014;14(12):1405-8.

49. Grae I. Nature's Colors - Dyes from Plants. MacMillan Publishing Co. New York 1974. ISBN 0-02-544950-8.

50. Allardice PA - Z of Companion Planting. Cassell Publishers Ltd. 1993. ISBN 0-304-34324-2.

51. Grieve. A Modern Herbal. Penguin: 1984. ISBN0-14-046-440-9

52. Rehman AU, Naz S, Zaman M, Saeed-ul-Hassan S, lqbal J, Zaidi AA. A preliminary investigation of in vitro anti-thrombotic and anti-platelet activity of Pinus gerardiana. Biomed Res. Ther. 2017;4(1):1098-109.

53. Troup RS. The Silviculture of Indian Trees. Clarendon Press: Oxford 1921;(3):1013-66

54. Dar AR. Taxonomic studies on gymnosperms in Kashmir. M.Phil. Dissertation, University of Kashmir, Srinagar-190006, J\&K, India. 2004.

55. Gamble JS. A manual of Indian Timbers. Sampson Low, Marston and Co.Ltd. London. 1902;868.

56. Aslam M, Reshi ZA, Siddiqi TO. Genetic divergence in half-sib progenies of Pinus wallichiana AB. Jackson plus trees in the Kashmir Himalaya, India. Tropical Ecology. 2011;52(2):201-8

57. Verma RL. Blessing of pine forests. Van Sandesh. 1988;9-13.

58. Variability in cone and seed characteristics among plus trees of blue pine (Pinus wallichiana AB jackson) in the Kashmir Himalaya, India. International Journal of Pharma. and Bio Sciences. 2010;1(4):212-23.

59. Naeem I, Taskeen A, Mubeen H, Maimoona. A Characterization of Flavonols Present in Barks and Needles of Pinus wallichiana and Pinus roxburghii. Asian J Chem. 2010;22(1):41-4

60. Rahman TU, Uddin G, Khattak KF, Liaqat W, Choudhary MI. Antibacterial, antifungal, insecticidal and phytotoxic activities of leaves of Pinus wallichiana. Journal of Chemical and Pharmaceutical Research. 2016;8:420-4.

61. Coppen JJ, Robinson JM, Kaushal AN. Composition of xylem resin from Pinus wallichiana and P roxburghii Phytochemistry. 1988;27(9):2873-5.

62. Sharma A. Joshi S, Kumar N. Antioxidant and antibacterial properties of leaves of Elaeocarpus sphaericus Roxb. and Pinus wallichiana from Uttarakhand region of India . International Journal of Green Pharmacy. 2015;9(4):246. 
63. Azmat A, Ahmed, KZ, Ahmed, M, Tariq B. Antinociceptive effects of poly herbal oil extract (PHOE). Pak J Pharmacol. 2006;23(2):1-7.

64. Rastogi S, Shukla A, Kolhapure SA. Evaluation of the clinical efficacy and safety of RG-01 (Rumalaya gel) in the management of chronic sub-acute inflammatory joint disorder. Med. Update. 2004;12(1):31-7.
65. Sharma A, Kolhapure SA. Evaluation of the efficacy and safety of Rumalaya gel in the management of acute and chronic inflammatory musculoskeletal disorders: an open, prospective, non-comparative, phase III clinical trial. Indian Journal of Clinical Practice. 2005;12(10):39-45
GRAPHICAL ABSTRACT

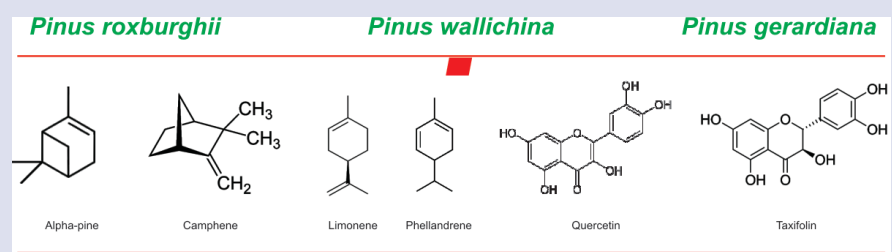

Anti-ulcer Hepatoprotective Anti-diabetic Anti-oxidant

Analgesic Anti-inflammatory Anti-microbial Antidyslipidemic

\section{SUMMARY}

- A pine is any conifer in the genus Pinus of the family Pinaceae.

- Pinus is the largest genus of monoecious, resiniferous, evergreen trees commonly known as Pines.

- Pinus roxburghii, Pinus wallichiana, Pinus gerardiana are native species of Pine from Himalayas.

- The constituents present in these pinus plant species are beneficial for the purpose of treatment of various ailments.

- The phytoconstituents and pharmacological activities of the pinus plant species confirm that the therapeutic value of these plants is very high, having a leading capacity for the development of a new, safe, effective and cheaper drug in future.

\section{ABOUT AUTHORS}

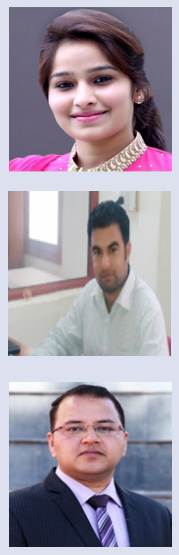

Aditi Sharma: (M.Pharm, Pursuing PhD) is working as an Assistant Professor (Pharmacology) in School of Pharmaceutical Sciences, Shoolini University.

Lalit Sharma: (M.Pharm, Pursuing PhD) is working as an Assistant Professor (Pharmacology) in School of Pharmaceutical Sciences, Shoolini University.

Dr. Rohit Goyal : (M.Pharm, PhD) Dr. Goyal is working as an Associate professor (Pharmacology) in School of Pharmaceutical Sciences, Shoolini University.

Cite this article: Sharma A, Sharma L, Goyal R. A Review on Himalayan Pine Species: Ethnopharmacological, Phytochemical and Pharmacological Aspects. Pharmacog J. 2018;10(4):611-9. 